ADAMIK BÉLA

\title{
A RÓMAI BIRODALOM HIVATALOS NYELVHASZNÁLATÁNAK TÖRTÉNETÉHEZ
}

\author{
A LATIN NYELV KELETI DOMINANCIÁJÁNAK OKAI \\ A DOMINATUS KORÁBAN*
}

\author{
SIGISMUNDO RITOÓK \\ IUVENTUTIS SEMPER ADHORTATORI \\ MAGISTRO SEPTUAGENARIO
}

A szakirodalomban a Római Birodalom hivatalos nyelvhasználatának Iustinianus ${ }^{1}$ elótti történetét általában két szakaszra szokták osztani: az első korszak a kései köztársaság és a principatus korával, a második korszak pedig a dominatus korával azonos. Tanulmányunkban azt a kérdést vizsgáljuk meg, hogy a dominatus korában miért változott meg a birodalom közigazgatásának nyelvhasználati, s azon belül is elsősorban nyelvválasztási gyakorlata. E célból először röviden leírjuk, hogy miben különbözött a principatus és a dominatus korának gyakorlata. Ezért először Kaimio eredményeire ${ }^{2}$ támaszkodva bemutatjuk a késő köztársaság-, ill. principatuskori, majd fő́ként Zilliacus munkáját ${ }^{3}$ felhasználva a dominatuskori gyakorlatot, utána pedig a változás okainak kérdésére próbálunk meg választ adni.

1. A késó köztársaság és a principatus kora. Az első korszakra vonatkozó elavult elképzelések továbbélését jól példázza, hogy a témával foglalkozó kutatók egy része mindmáig hitelt ad Valerius Maximus egyik állításának, ${ }^{4}$ melyből — valamint még

* Elhangzott az Ókortudományi Társaság felolvasó rendes ülésén 1999. március 19-én.

${ }^{1}$ Iustinianus 534-es nyelvhasználati reformjáról 1. az Ant. Tan. következő számában publikálásra kerüló dolgozatomat.

2 Jorma Kaimio: The Romans and the Greek Language. Helsinki 1979 (Commentationes Humanarum Litterarum 64, Societas Scientiarum Fennica); a még ma is modernnek tekinthetô, szociolingvisztikai megközelítésú, $\mathrm{s}$ egyben filológiailag is kitúnő monográfia eredményei mindmáig nem váltak a szakmai tudat közkincsévé, amit jól mutat a kérdésnek egy újabb, de szemléletében elavult és sikertelen összefoglalása is: Bruno Rochette: Le latin dans le monde grec. Recherches sur la diffusion de la langue et des lettres latines dans les provinces hellénophones de l'Empire romain. Bruxelles 1997 (Collection Latomus 233).

${ }^{3}$ Henrik Zilliacus: Zum Kampf der Weltsprachen im oströmischen Reich. Amsterdam $1965^{2}$ (= 1935 Helsingfors).

${ }^{4}$ Valerius Maximus 2.2.2: Magistratus uero prisci quantopere suam populique Romani maiestatem retinentes se gesserint hinc cognosci potest, quod inter cetera obtinendae grauitatis indicia illud quoque magna cum perseuerantia custodiebant, ne Graecis umquam nisi latine responsa darent. quin etiam ipsos linguae uolubilitate, qua plurimum ualent, excussa per interpretem loqui cogebant non in urbe tantum nostra, sed etiam in Graecia et Asia, quo scilicet Latinae uocis honos per omnes gentes uenerabilior diffunderetur. nec illis deerant studia doctrinae, sed nulla non in re pallium togae subici debere arbitrabantur, indignum esse existimantes inlecebris et suauitati litterarum imperii pondus et auctoritatem donari. 
néhány szintén félreértelmezett szöveghelyből - azt a következtetést vonták le, hogy a római birodalomban a kései köztársaság, sốt egyesek szerint még a principatus idején is lényegében egyetlen és kizárólagos hivatalos nyelv létezett: a latin. ${ }^{5}$ Kaimio a feliratos és irodalmi források alapos vizsgálatával kétséget kizáróan bebizonyította, hogy Valerius Maximusnak a birodalom keleti részére vonatkozó nyelvhasználatot érintô állításai alaptalanok: ${ }^{6}$ az általános szabály éppen az volt, hogy a görög közösségekre vonatkozó hivatalos iratokat abban a korban, amelyre Valerius utal, görögül készítették, vagy görögre fordították, és így publikálták őket. $^{7}$

Kaimio a különféle források vizsgálatával kimutatta, hogy a késő köztársaságés principatuskori birodalmi adminisztrációban nyelvi dichotomia létezett, azaz a birodalmat nyelvhasználat szempontjából latin és görög részre osztották fel. A nyelvválasztás nem a beszélő́k anyanyelvétől függött, hanem territoriális alapú volt, ezért ezt az elvet illetve gyakorlatot a finn kutató bilaterális unilingualizmusnak nevezte el. ${ }^{8}$ E dichotomia intézményesülésére utal, hogy Claudius vagy Nero uralkodásától fogva a birodalmi „kancelláriát” ab epistulis Graecis és ab epistulis Latinis hivatalokra osz-

${ }^{5}$ Először Ludwig Hahn: Rom und Romanismus im griechisch-römischen Osten. Mit besonderer Berücksichtigung der Sprache. Bis auf die Zeit Hadrians. Leipzig 1906, 110. sk., 212. Majd ennek folytatásában: Ludwig Hahn: Zum Sprachenkampf im römischen Reich bis auf die Zeit Justinians. Philologus Suppl. 10 (1907) 675-718; 694. skk. (lentebb Hahnnak csak e munkájára hivatkozunk). Hahnt követi Rüdiger Schmitt: Die Sprachverhältnisse in den östlichen Provinzen des Römischen Reiches. ANRW 2. 29. 2. Berlin—New York 1983, 554-586; 561, Michel Dubuisson: La place du grec dans la société romaine: à propos d' propos d'un ouvrage récent [J. Kaimio: i.m.]. RBPh 63 (1985) 108-115; 114. és B. Rochette: i.m. 89. skk. Tanulságos Hubert Petersmann elhibázott megjegyzése is: „Daß auch in der Kaiserzeit die römischen Beamten in offizieller Mission sich immer des Lateinischen bedienten, bezeugt Valerius Maximus 2,2,2.”, Hubert Petersmann: Vulgärlateinisches aus Byzanz. Zum Umgang mit fremden Sprachen in der Griechisch-Römischen Antike. Ed. C. W. Müller et al. Stuttgart 1992, 219-231; 220. 4. jz.

${ }^{6}$ Itt jegyezzük meg, hogy a császárkori kompilátor, aki Tiberiusnak ajánlotta múvét, nem saját kora viszonyait, hanem saját maga és császára vágyait próbálta meg visszavetíteni a múltba. Korának nyelvi filhellénizmusát kritizálva fordult a „régi szép idôk” gyakorlatához, amelyet ő maga konstruált néhány elszigetelt eset alapján, valóságot vegyítve a fikcióval. Ez a módszer egyébként Valerius egész munkájára igaz, hiszen nem történettudományi munkáról van szó, hanem átstilizált, megszerkesztett retorikai példatárról. Hogy megfelelő hatást érjen el — mutat rá Adamik Tamás: Római irodalom az ezüstkorban. Budapest 1994, 36. sk. - , olykor változtat is a történeti igazságon, követve Cicerónak azt a tanácsát, hogy „meg van engedve a rétoroknak, hogy hozzáköltsenek a történeti eseményekhez olyan célból, hogy elmésebben adhassák elő" (Brutus 42). E cél érdekében olykor felnagyítja a történetet és feszültséget teremt, hogy a végén meglepetést okozzon az olvasónak.

${ }^{7}$ A görög keletre vonatkozó köztársaságkori és Augustus-kori római dokumentumok gyújteményének hetvenhét felirata közül mindössze három bilingvis (latin-görög), a többi görög nyelvú, ami azt mutatja, hogy a görög közösségek csak görög nyelven kapták meg e szövegeket, J. Kaimio: i.m. 75., R. K. Sherk: Roman Documents from the Greek East. Baltimore 1969. anyagára hivatkozva.

8 J. Kaimio: i.m. 129; 319. sk. Pontos határvonalat e két nyelvhasználati territórium között meghúzni nehéz lenne, de ez valószínúleg azonos azzal az elválasztó sávval, amelyet a latin és a görög feliratok között lehet húzni a Balkánon, tehát a Dalmatia és Macedonia valamint Moesia és Thracia provinciák közti határvonallal. Vö. Boris Gerov: Die lateinisch-griechische Sprachgrenze auf der Balkanhalbinsel. Die Sprachen im römischen Reich der Kaiserzeit. Kolloquim vom 8-10. April 1974. (Beih. BJ 40). Ed. G. Neumann—J. Untermann. Köln—Bonn 1980, 147-165. 
tották fel, ${ }^{9} \mathrm{~s}$ hogy a görög területekre vonatkozó császári rescriptumokat a principatus korában rendszeresen görögül publikálták. ${ }^{10} \mathrm{Ez}$ a dichotomia a principatuskori császárok számára minden bizonnyal természetes és magától értetődô volt ${ }^{11} \mathrm{~s}$ annyira szilárdnak bizonyult, hogy az egyes császárok személyes nyelvi attitúdje csak nagyon kis mértékben tudta azt befolyásolni. ${ }^{12}$

A birodalom nyugati felében tehát természetesen a latint, a keleti felében pedig a görögöt használták. Keleten azonban a latin nyelv is szerephez jutott, de csak a központi kormányzat és a római magistratusok közötti, a római magistratusok és a római kolóniák közötti kommunikációban, valamint a római kolóniákon belül, és bizonyos mértékben a római polgárokkal kapcsolatban. A római senatus határozatait, a császárok, ill. római magistratusok leveleit és edictumait, amelyek a görög kö-

${ }^{9}$ J. Kaimio: i.m. 117; 319. sk. A hivatal munkakörét jól leírja a 4. század végéről származó Notitia Dignitatum, Oriens c. 17, 4. (ed. Böcking): Magister epistolarum Graecarum eas epistolas, quae Graece emitti solent, aut ipse dictat aut Latine dictatas transfert in Graecum. Az ab epistulis hivatalhoz I. Der Kleine Pauly és Der Neue Pauly s.v. epistulis.

${ }_{10}$ A rescriptum a császári rendeletek (constitutiones) egyik fajtája, tulajdonképpen konkrét, vitás jogi ügyekben hozott elvi döntés, leirat formájában. Már H. Zilliacus: i.m. 68-70. észrevette a keletre címzett rescriptumok görög nyelvưségét Iustinianus Digestájának következő helyei alapján (beazonosítá-

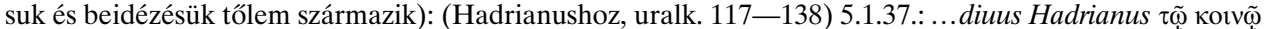
$\tau \tilde{\omega} v \theta \varepsilon \sigma \sigma a ́ \lambda \omega \nu$ Graece rescripsit; (Antoninus Piushoz, 138-161) 48.3.3. pr.: Diuus Pius ad epistulam Antio-

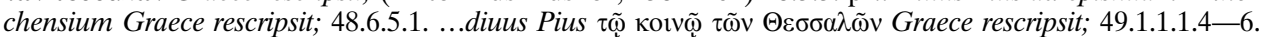

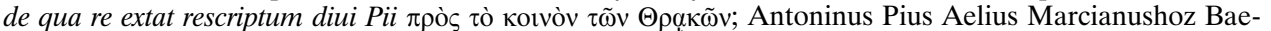
tica proconsulához viszont latinul küldte el rescriptumát (kiegészítés tólem), 1.6.2.pr.3—4. cuius rescripti uerba haec sunt: 'Dominarum quidem potestatem in suos...; (Helvius Pertinaxhoz, 192-193) 50.6.6.2 ex

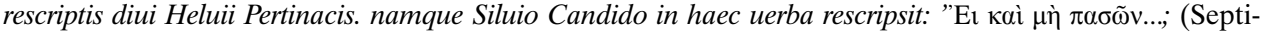
mius Severushoz 193-211) 16.1.2.2.: est et Graecum Seueri tale rescriptum: $\tau \alpha \tilde{\iota} \varsigma \dot{\alpha} \pi \alpha \tau \omega ́ \sigma \alpha \iota \varsigma ~ \gamma o v \alpha 1 \xi ı . . . ~(S e-$

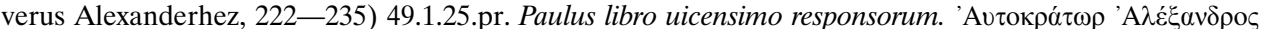

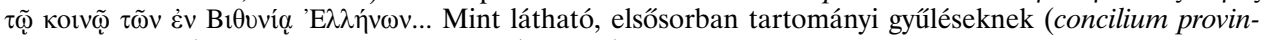

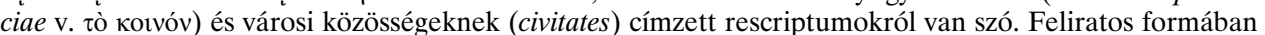
is számos (84) görög nyelvú, a császároktól görög közösségekhez küldött levél maradt fenn, vö. $H$. Zilliacus: i.m. 69., aki L. Lafoscade: De epistulis aliisque titulis imperatorum magistratumque Romanorum quas ab aetate Augusti usque ad Constantinum Graece scriptas lapides papyrive servaverunt. Insulis 1902. anyagára hivatkozik.

${ }_{11}$ Erre utal az a Suetonius-hely is, mely szerint az ifjú Nero görögül tartotta meg beszédét Rhodos és Ilion, míg latinul Bononia érdekében, Suetonius, VC, Nero 7,2: apud eundem consulem pro Bononiensibus Latine, pro Rhodis atque Iliensibus Graece uerba fecit. Vö. J. Kaimio: i.m. 116. Az eset feljegyzése mutatja, hogy Nero eljárása valószínúleg szokatlannak számított, tehát, hogy a császár nem csak rendeletei nyelvválasztásában, hanem személyes senatusi felszólalásaiban is megpróbálta ezt a dichotomiát érvényesíteni (vö. ezzel szemben Tiberius magatartását, l. a köv. jegyzetben).

12 Sem a hellénofób sem a filhellén császárok nem tudták és nem is akarták azt érdemben befolyásolni. Hellénofób császár egyébként nagyon kevés akadt — Claudiust inkább a filhellén császárok közé sorolnám —, talán csak a görög nyelvet amúgy kiválóan ismeró Tiberiust lehet ide venni, aki leginkább a senatusban próbálta meg korlátozni a görög nyelv használatát: Suetonius VC. Tib. 71.1.: sermone Graeco quamquam alioqui promptus et facilis, non tamen usque quaque usus est abstinuitque maxime in senatu. Ami a filhellén császárokat illeti, Kaimio megállapítja, hogy Augustustól Diocletianusig minden császár tudott görögül, s a következőket sorolja a filhellén császárok közé (akikről ez egyáltalán megállapítható): részben Claudius, Nero, Traianus, Hadrianus, Marcus Aurelius, valószínúleg Septimius Severus, Severus Alexander, Gordianus és Gallienus. A tárgyalt kor egyik császára sem vonta kétségbe a görög második (vagy másik) hivatalos nyelvi szerepét, s ugyanakkor még a legfilhellénebb császár sem tette meg a görögöt a birodalom első nyelvévé. Vö. J. Kaimio: i.m. 130-143. 
zösségekre vonatkoztak — legyen az város, vagy tartomány —, eleve görögül írták, vagy ha Rómában latinul készültek, akkor rögtön görögre fordították. ${ }^{13}$ Látható tehát, hogy a latin nyelv keleten elsősorban egyfajta „belsô” használatban kapott szerepet, míg „kifelé” a római közigazgatás minden szinten görög nyelven jelent meg. ${ }^{14}$ A latin nyelv keleten csak két területen szerzet domináns pozíciót: a hadsereg magasabb szintú adminisztrációjában és a jog területén a római polgárjoggal kapcsolatos dokumentumok nyelvhasználatában. ${ }^{15}$ Más, a birodalomban beszélt nyelv nem játszott szerepet a római közigazgatásban, csak a helyi, lokális adminisztrációban használhatták esetleg ôket, korlátozott mértékben. ${ }^{16}$

A görög nyelv kivételes helyzetét elsősorban annak köszönhette, hogy már a római uralom előtt a mediterráneum nemzetközi presztízsnyelvévé vált. A keleti, hellénisztikus birodalmakat magába olvasztó Római Birodalom, amely magát eme országok jogos örökösének tekintette, a görög nyelvet is mintegy örökbe kapta, s így magáénak tartotta. A keleti közigazgatás „kifelé” irányuló görög nyelvúségének fenntartásában minden bizonnyal az a politikai elképzelés is szerepet játszhatott, hogy a görög keleten Róma mint hellénisztikus birodalom jelenjék meg, így fogadtatva el magát a keleti mediterráneum urának.

Másik fontos megfigyelése a finn kutatónak - amelyre dolgozatunk végén jelentősége miatt még visszatérünk -, hogy a hivatalos nyelvhasználat írásban lényegében nem vagy alig volt szabályozva. Az ilyesfajta rendelkezések ritkaságából, illetve hiányából Kaimio arra következtetett, hogy korunkkal szemben az antikvitásban a hivatalos nyelvhasználat kérdése egyáltalán nem, vagy csak kevéssé volt fontos, illetve, hogy a nyelvhasználatot nem annyira valamiféle írásos szabályozás, mint inkább a tradíció irányította. A római nyelvpolitika, ha egyáltalán ilyenról beszélhetünk, a göröggel szemben lényegében védekező pozíciót foglalt el, és a birodalom urai nem erőltették keleten a latin nyelv terjesztését, ami nem meglepő, mivel nyugaton sem

13 Vö. J. Kaimio: i.m. 129.

${ }^{14}$ J. Kaimio: i.m. 89. szerint Róma a görög birodalomrészben egyenesen a görög hivatalos használatát támogatta Pl. Moesia Inferiornak a latin-görög nyelvi határtól délre esố területein. A Traianus császár által Kr. u. 102-ben alapított Marcianopolisnak és Nicopolisnak nemcsak a neve volt görög, hanem „alkotmánya” és közigazgatási nyelve is, noha a lakosságnak valószínúleg csak a kisebbik része volt görög anyanyelvú, a nagyobb része latin nyelvú volt. Nicopolisban különösen sok hivatalos felirat íródott kizárólag görögül. Vö. még B. Gerov: i.m. 159-163.

${ }^{15}$ Kaimio rámutat, hogy elsősorban a katonai egységek egészére vonatkozó dokumentumoknál használták a latint; a katonák egymás közti kommunikációjában természetes és magától értetôdő volt a görög használata; a leszerelési dokumentumok latinul íródtak (mert a polgárjog megadását is tartalmazták), míg a katonák átvételi elismervényei (pénzrôl, terményekrôl stb.) görögül; a római civil magistratusok latinul írtak a katonai egységeknek, de görögül az egyes katonáknak; a hadsereg görögül érintkezett a helyi hivatalnokokkal és a civil lakossággal. A jogi nyelvhasználatban annak ellenére domináns volt a latin, hogy a törvények publikálásában és a iurisdictioban a görög nyelv a latinnal egyenrangú volt; a római polgárjogúak számára keleten is kötelező volt a latin nyelv használata, mégis a ius civile területéhez tartozó néhány dokumentumtípusnál, de a végrendeleteknél a katonáknak Kr. u. 150-től, a római polgárjogúaknak pedig Severus Alexander uralkodásától (222-235) fogva megengedték a görög nyelv használatát is. Vö. J. Kaimio: i.m. 143. skk., ill. 153. skk.

16 Vö. J. Kaimio: i.m. 129. 
beszélhetünk a latin nyelv tudatos terjesztésérôl, és az alávetett népekre való rákényszerítéséról. ${ }^{17}$

2. A dominatus kora. Már abból a tényből, hogy a dominatus korát elkülönítik az előzőtól, kiviláglik, hogy a fent ismertetett gyakorlat valamilyen irányban megváltozott. A harmadik századi források nyelvhasználatának Kaimio által elvégzett vizsgálata azt mutatja, hogy a bilaterális unilingualizmus tradíciója megrendült, és a nyelvhasználati gyakorlat a korábbi századokhoz képest összezavarodott.

Ami a hivatalos dokumentumok nyelvválasztását illeti, megállapítható, hogy a második század vége felé és különösen a harmadik században a görög közösségeknek küldött dokumentumok már nem mindig görög nyelven íródtak, megjelennek a kizárólag latinul írott törvények. A görög nyelven beadott libellikre (beadványokra) latin subscriptiok (válaszirat, a rescriptum egyik fajtája) válaszolnak. Különösen a harmadik század közepétôl fogva válik gyakorlattá a latin nyelv használata a keletre címzett dokumentumokban. Diocletianustól kezdve $-\mathrm{s}$ itt Kaimio elsôsorban már csak tanárának, a szintén finn Zilliacusnak 1935-ben megjelent és 1965-ben másodszorra is kiadott disszertációjára támaszkodik — a keletre vonatkozó császári constitutiók (rendeletek) nyelve a korábbi gyakorlattal ellentétben kizárólag a latin lesz. ${ }^{18}$ Ezzel párhuzamosan a pénzek görög feliratozása keleten Diocletianus uralma alatt megszúnik, és csak latin feliratos érméket vernek ${ }^{19} \mathrm{Az}$ ô uralma alatt Egyiptomban a bírósági perek jegyzőkönyveit már kizárólag latinul írták, noha a tárgyalás nyelve a görög maradt. ${ }^{20}$ Constantinus uralkodása alatt keleten a hivatalos feliratokon a latin nyelv használata általános, görög nyelvú csak igen ritkán fordul elô. ${ }^{21}$ Ugyanez áll utódaira is, még a filhellén Iulianus alatt sem változik meg ez a gyakorlat, annyira nem, hogy még a görög városok is latin nyelvú feliratokat állítanak az Apostata tiszteletére! Csak a birodalom, illetve az afölötti uralom végleges kettéosztása előtti utolsó idôszakban kezdenek megjelenni újra a görög nyelvú feliratok, mégpedig az ötödik századra oly jellemző bilinguis formában, melynek elsố példája Nagy Theodosius constantinopolisi felirata. ${ }^{22}$

${ }^{17}$ Sőt sokszor maguk az alávetett népek, illetve vezetőik látták be, hogy nemcsak szükséges, de hasznos számukra a latintudás. Ez világosan kiderül egy a szakirodalomban sokat idézett Livius-helyből is (40.42.13.): Cumanis eo anno petentibus permissum, ut publice Latine loquerentur et praeconibus Latine uendendi ius esset. (a Kr. e. 180-as évről). Vö. J. Kaimio: i.m. 326. skk.

${ }^{18}$ Vö. J. Kaimio: i.m. 121. a forráshelyek megadásával és H. Zilliacus: i.m. 90.

19 Vö. J. Kaimio: i.m. 93. és H. Zilliacus: i.m. 50.

${ }^{20}$ A papyrusok alapján megállapítható, hogy Diocletianus előtt ezeket a jegyzőkönyveket kizárólag görögül írták, Vö. J. Kaimio: i.m. 93. és H. Zilliacus: i.m. 90. sk., kül. 97.

${ }^{21}$ Constantinus nevével számos latin feliratot ismerünk Syriából, Kappadokiából, Galatiából, Pontusból és Bithyniából, valamint Asiából, ezek között sok a mérföldkő. Lykiából latin nyelvú subscriptióját is ismerjük, a mellékelt görög nyelvú libellussal együtt (CIL III, $12132=13625)$, a phrygiai Orcistumból pedig töredékesen a lakosok beadványára írt subscriptióját (CIL III, 352). Vö. H. Zilliacus: i.m. 40—41.

${ }_{22}$ Részletesen, a 4. századi feliratos források helymegadásával 1. H. Zilliacus: i.m. 39—43. 
Ezek a megállapítások elsősorban a 30-as évek kutatási eredményein alapulnak. Az azóta előkerült forrásanyag vizsgálata lehet, hogy ezt a képet valamennyire módosítani fogja, de e forrásanyag ilyen szempontú feldolgozása mindmáig nem történt meg. Ma már azonban az informatika robbanásszerú fejlódésének köszönhetôen a keleti birodalomrészben keletkezett dokumentumok - elsôsorban papyrusok és feliratok - CD-lemezen is elérhetôk. Ha csak a görög közösségek részéról a császárok tiszteletére emelt feliratokat nézzük meg e CD-lemezen, kiderül, hogy a negyedik században ezek többségükben továbbra is görög nyelvúek, de természetesen latin nyelvúek is elófordulnak. ${ }^{23}$ Hivatkozhatunk Turner megfigyeléseire is, aki két, hivatalos leveleket tartalmazó egyiptomi papyruscorpust vizsgált meg. E 3-4. század fordulóján keletkezett dokumentumoknál a latin nyelvet csak a formalitásoknál, elsôsorban a datálásoknál használták, a lényegi mondanivaló mindenhol görögül íródott. ${ }^{24}$ Úgy túnik tehát, hogy a dominatus korában a görög nyelv az eddig feltételezettnél jelentősebb szerepet játszott keleten, de megjelenik mellette korábban nem tapasztalt mértékben a latin is.

Hasonló megállapításra juthatunk a metalingvisztikai források elemzésével is. E nem túl számos irodalmi utalás többsége I. Constantinus hivatalos nyelvhasználatáról, ill. nyelvválasztásáról tesz megjegyzéseket. E szövegek értelmezésénél óvatosan kell eljárni, mert a szövegkörnyezetből kiragadt idézetek olykor túlzó, sốt hamis következtetések levonását eredményezhetik. Egyes kutatók például a Vita Constantini 4.19. egyik mondatából azt a következtetést vonták le, hogy a hadseregben Constantinus kötelező érvénnyel előírta a latin nyelv használatát. ${ }^{25}$ A caput arról szól, hogy Constantinus elrendelte többnyire pogány katonáinak: vasárnaponként imádkozzanak az Úrhoz. Miután részletesen elmondta, mit s miért kell tenniük, e sorok

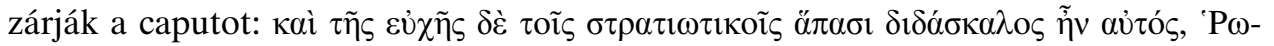

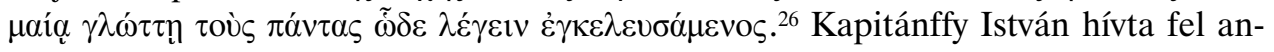
nak idején a figyelmemet arra, hogy e szövegben nem a latin nyelv általános és kötelezô elôírásáról van szó, hanem csak egy konkrét ima latin nyelven való elmondásának megköveteléséról. Annyit azért mindenesetre ki lehet olvasni Eusebios tudósításából, hogy Constantinus, ha nem is tette kötelezővé katonáinak a latin nyelvet,

${ }^{23}$ A Packard Humanities Institute (PHI), Disk \# 7 (Papyri and Inscriptions) 1996 CD-rom hatalmas görög feliratgyúiteményében számos görög feliratot találunk, melyeket görög városok emeltek pl. Constantinus tiszteletére, többek között Paroson, Asia Minorban és Egyiptomban.

${ }^{24}$ Eric G. Turner: Latin versus Greek as a Universal Language: the Attitude of Diocletian. Language and Society. Essays presented to Arthur M. Jensen. Copenhagen 1961, 165-168; 167. A két corpust 1960-ban publikálták.

${ }^{25}$ „Dans l'armée, l'influence de la langue latine a atteint son point culminant au début du IVe

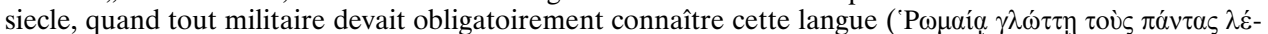

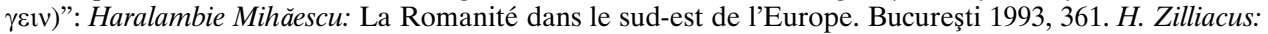
i.m. 128-ra hivatkozva, aki pedig (mint annyi más helyen) L. Hahn: i.m. 701. megfogalmazását vette át: „Konstantin... seinen Soldaten den Gebrauch der lateinischen Sprache vorschrieb”. Az idézésnek ez a módja teljesen félrevezetô.

${ }^{26}$ A 20. caputban következik az ima görög fordítása. 
minden bizonnyal elvárta katonáitól annak ismeretét. Ezt az elvárását motiválhatta, hogy a késôrómai hadsereg tisztikara éppen az ô uralkodásától kezdve növekvő mértékben barbárokból, mindenekelōtt germánokból állt. ${ }^{27}$ Ez az elvárás továbbá teljesen összhangban volt a hadsereg korábbi nyelvhasználati gyakorlatával, amenynyiben a hadsereg egészére illetve egységeire vonatkozóan keleten korábban is a latin nyelvet használták - és itt is a katonák egészérốl van szó. Minőségi változást tehát ez a szöveg — a korábbi véleményekkel ellentétben — az első korszakhoz képest nem tükröz.

A következő helyekboól kitûnik, hogy Constantinus a hivatalos megnyilatkozásainál tényleg a latint részesítette elônyben. A Bosporus közelében fekvő Nicaea városában tartott első birodalmi zsinaton, Kr. u. 325-ben rendszerint latinul szólt az egybegyúlt püspökökhöz, s tolmács fordította szavait görögre, pl. Vita Constantini

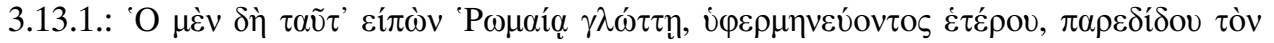

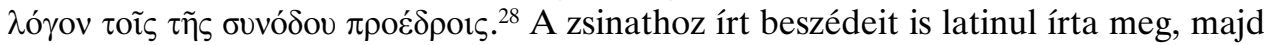

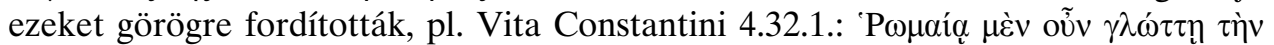

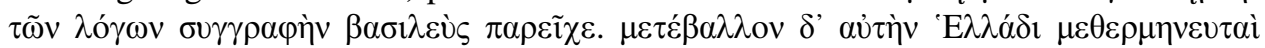

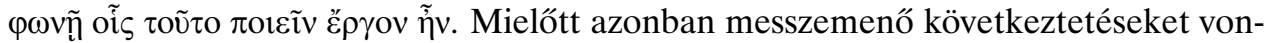
nánk le e helyekből, érdemes a Vita Constantini 3.13.-at tovább olvasni. Az egyházatyák a császár latin beszédét követôen olyan vitába bonyolódtak, hogy a zsinat majdnem zúrzavarba fulladt, s magának Constantinusnak kellett közbelépnie, s kitartóan tárgyalva velük, lassan megbékítette a viszálykodókat: $\pi \rho \alpha ́ \omega \varsigma ~ \tau \varepsilon \pi 010 v ́ \mu \varepsilon v o \varsigma$

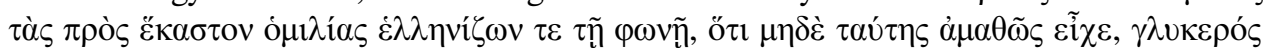

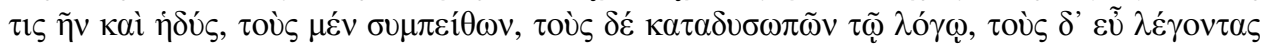

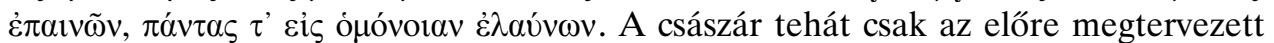
hivatalos megnyilatkozásainál használta a latin nyelvet, s amint ebből a szerepéből kiesett, spontán megnyilatkozásainál rögtön áttért a görög nyelvre, hogy a kommunikációt meggyorsítsa, s hogy — talán tudatosan — a görög nyelvú püspököket ezzel is magához édesgesse. ${ }^{29}$

Hogy a latin használata csak domináns, de nem kizárólagos volt Constantinus hivatalos, írásban rögzített megnyilatkozásainál, az a következő szövegből is kiderül. A Vita Constantini 2.23. arról szól, hogy a császár, miután isten segedelmével Licinius halálát követôen - mindent uralma alá hajtott, kinyilvánította, hogy győ-

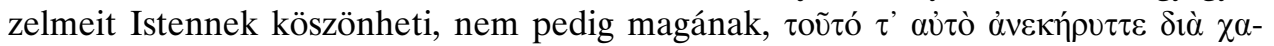

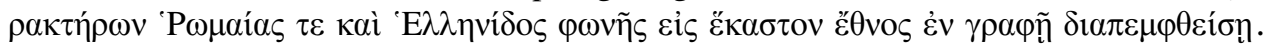

27 Vö. Alföldy Géza: Római társadalomtörténet. Budapest 1996, 117.

28 Így kezdódik a 13. caput, maga a beszéd görög fordításában a 12. caputban olvasható. Ugyanígy

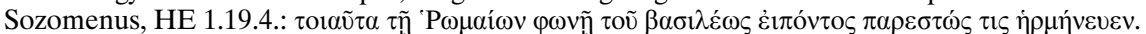

${ }^{29}$ Hogy a görögül tudó császár mennyire ragaszkodott a görögökkel folytatott hivatalos kommunikációban a latin nyelvhez, azt jól szemlélteti a Codex Theodosianusban ránk maradt töredékes, a peres eljárások jegyzőkönyvére emlékeztetô párbeszédes szöveg $(8,15,1)$. Egy bizonyos Agrippina görögül tesz vallomást, utána Constantinus latinul teszi meg észrevételeit és kérdéseit, amelyekre Agrippina görögül válaszol, majd a császár latinul hirdeti ki döntését. A helyre Rihmer Zoltán hívta fel a figyelmemet. 
Jellemző, hogy erre a helyre Hahn úgy hivatkozott, hogy az a latin nyelv kizárólagos használatát bizonyítja. ${ }^{30}$ A Vita több helye alapján biztosra vehetjük, hogy a keleti provinciákban a görög nyelvú változatot publikálták. ${ }^{31}$

A források alapján tehát megállapítható, hogy a dominatus korának hivatalos nyelvhasználatában keleten a latin nyelv a korábbinál jóval dominánsabb, de nem kizárólagos szerepet töltött be, ugyanakkor a görög nyelv nem szorult annyira háttérbe, mint ahogy ezt eddig feltételezték. ${ }^{32}$

3. A latin nyelv dominanciájának okai. Felmerül a kérdés, hogy mivel magyarázható a latin nyelv használatának dominanciája a tárgyalt korban és területen? A kutatók mindmáig úgy gondolják, hogy ez a dominancia csak egyféleképpen magyarázható: tudatos nyelvpolitikai váltással. E kutatók közé tartozik, hogy csak a jelentősebbeket említsem, Ludwig Hahn, Henrik Zilliacus, Gilbert Dagron, Arnold Toynbee, a Kahane-házaspár, Hubert Petersmann, de még Eric Turner — igaz, jóval viszszafogottabban - és Jorma Kaimio is, utóbbi valószínúleg csak azért, mert Zilliacus tanítványa volt. ${ }^{33}$ E kutatók feltételezik, hogy az illír katonacsászárok (268-284) a harmadik századi összeomlást követôen a birodalom egységét a hivatalos nyelvhasználat uniformizálásával is erősíteni akarták, és a nyelvi dualizmust károsnak tartották. E politika csúcspontját Constantinus uralkodása jelentette volna, aki - szerintük - tervbe vette a keleti területek romanizálását, és e romanizációs program keretében alapította meg új székvárosát: Constantinopolist. Hogy Constantinopolis megalapítása milyen okból történt, azzal most nem foglalkozhatunk, de annyi bizonyos, hogy a város alapításában semmiféle romanizációs vagy latinizációs szándék nem játszott szerepet. ${ }^{34}$

${ }^{30}$ Lásd L. Hahn: i.m. 702., megjegyzését szó szerint átvette H. Zilliacus: i.m. 23., aki a 70. oldalon viszont megfeleló összefüggésben idézi a helyet.

${ }^{31}$ Eusebios egyébként csak annyit árul el a rendelet publikálási módjáról, hogy az két levélbôl állt: az egyik az egyházhoz szólt, a másik a városok pogány lakosságához. Ez utóbbi típusra viszont Eusebios példaként idézi teljes terjedelemben a rendelet Palestina provinicia lakóinak címzett példányát, s hozzáteszi, hogy ezt a nála lévő autentikus példány alapján közli, majd következik a görög szöveg a Vita 2.2442.-ben. Mivel nem utal arra, hogy latinból készült fordítást közöl - máskor viszont ezt mindig megteszi —, feltételezhetjük, és a Vita egy másik helye alapján pedig biztosra vehetjük, hogy a keleti provinciákban

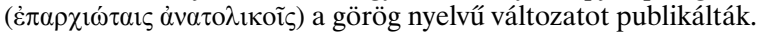

${ }^{32}$ Ezt megerősíti az a tény is, hogy a magister epistolarum Graecarum tiszte a dominatus korában is létezett, 1 . a negyedik század végén keletkezett Notitia Dignitatum fentebb idézett helyét.

${ }^{33}$ L. Hahn: i.m. 701., H. Zilliacus: i.m., 17., Gilbert Dagron: Aux origines de la civilisation byzantine: Langue de culture et langue d'État. Revue Historique 241 (1969) 23-56; 38. sk., Arnold Toynbee: Constantine Porphyrogenitus and His World. London 1973, 557., Henry és Renée Kahane: Decline and Survival of Western Prestige Languages. Language 55 (1979) 183-198; 185., Hubert Petersmann: Die Urbanisierung des römischen Reiches im Lichte der lateinischen Sprache. Gymnasium 96 (1989) 406-428; 410., E. G. Turner: i.m. 168., J. Kaimio: i.m. 330. A téma legutóbbi összefoglalója B. Rochette: i.m. 9. szintén vallja, hogy: „Dioclétien... inscrivit dans son programme politique l'instauration du latin comme langue administrative de tout l'Empire."

${ }^{34}$ Constantinopolis alapításának okairól 1. Moravcsik Gyula: Bevezetés a bizantinológiába. Budapest $1989^{2}, 7$. sk. 
Milyen korabeli források alapján tételezik fel a kutatók, hogy ilyen nyelvpolitika létezett? Egyrészt a dokumentumok nyelvhasználatában bekövetkezett változás, másrészt a fent bemutatott, kétes értékú irodalmi utalások, de leginkább egy tulajdonképpen nem is kortárs szöveg kiragadott mondata alapján. Augustinus a De civitate Dei 19. 7-ben arról ír, hogy a nyelvi különbségek mennyire megosztják az emberi társadalmat (in quo primum linguarum diversitas hominem alienat ab homine), aminek az a következménye, hogy libentius homo sit cum cane suo, quam cum homine alieno, s amikor megpróbálták e különbségeket áthidalni, ez csak újabb háborúkhoz és szenvedésekhez vezetett. A szakirodalomban sokat idézett mondat a következóképpen hangzik: At enim opera data est, ut imperiosa civitas non solum iugum, verum etiam linguam suam domitis gentibus per pacem societatis imponeret; per quam non deesset, immo et abundaret etiam interpretum copia. ${ }^{35}$ Augustinus szerint tehát megkísérelték a nyelvi különbségeket áthidalni a birodalomban, nyilván a Rómaiban, az imperiosa civitas nyelvének rákényszerítésével a meghódítottakra: de milyen áron? verum est, sed hoc quam multis et quam grandibus bellis, quanta strage hominum, quanta effusione humani sanguinis comparatum est? A caput további részében pedig a háború okozta szenvedésekrôl és csapásokról mondja el a véleményét. Augustinus e múvét 410 után írta, és benne cáfolni akarta a pogányok vádjait, miszerint Róma Alarich általi elfoglalása és kifosztása a kereszténységnek köszönhető, továbbá felvázolta egy keresztény történelemfilozófia alapjait. A De civitate Dei keletkezési körülményeinek, tartalmának és céljainak ismeretében e mondatot nyilván nem szabad teljesen komolyan vennünk, ráadásul annyira általános a megfogalmazása, hogy nem derül ki belőle: a Római Birodalom melyik korszakában történt ez a kísérlet, milyen területen és milyen mértékben, pontosan milyen eszközökkel stb. Augustinus egész életében a birodalom nyugati részében tevékenykedett (Thagaste, Róma, Milánó, Hippo Regius), azaz a birodalom latin nyelvú részében élt. Nyilván feltúnt neki, hogy mennyi nép él a birodalomban, de a hivatalos kommunikációban (nyugaton) csak a latint használják. Ebből vonta le azt a konklúziót, hogy a latin nyelv elterjedése elterjesztés eredménye. Tehát ő volt az első „kutató”, aki ebben tudatos elképzelést, mai szóval „nyelvpolitikát” tételezett fel, így Augustinus bizonyos tekintetben Ludwig Hahn, Henrik Zilliacus és követôii előfutárának tekinthető. Kortárs forrásunk tehát nincsen arra vonatkozóan, hogy az illír katonacsászárok, illetve a dominatus elsố uralkodói tudatosan terjesztették volna a latin nyelvet a birodalom keleti felében. Marad a dokumentumok nyelvhasználatában megfigyelhetô latin dominancia mint olyan tény, mely véleményünk szerint is mindenféleképpen magyarázatot igényel.

Hahntól, Zilliacustól, Petersmanntól és még sok más kutatótól eltérôen én nem tudatos nyelvpolitikával, latinizációs, ill. romanizációs szándékkal magyarázom e jelenséget, hanem egy sokrétú, bonyolult és legnagyobbrészt spontán folyamat

35 „De arra is törekedtek, hogy a hatalmas városállam ne csak az igáját, hanem a nyelvét is rákényszerítse a béke köteléke révén a meghódított népekre; de ezáltal nemhogy csökkent, hanem inkább csak gyarapodott a tolmácsok serege." 
eredményének tartom a latin nyelv dominanciáját a tárgyalt korban és területen. A latin nyelv előtérbe kerülése a dominatus megváltozott uralmi, közigazgatási, társadalmi viszonyainak köszönhetô. Hogy egy szemléletes példával éljek, a fent felsorolt szerzők egyik sokszor hangoztatott érve a latin nyelv tudatos előtérbe helyezésére és a görög nyelv háttérbe szorítására az a jelenség, hogy Diocletianus uralma alatt keleten megszúnik a görög nyelvú pénzverés és csak latin feliratos pénzeket állítanak eló. Itt valószínúleg arról van szó, hogy a dominatusban, amely a központi hatalom alá gyứrt minden autonómiát $\mathrm{s}$ megszüntetett minden korábbról maradt kiváltságot, területi önállóságot, a pénzverést is központosították, s a központi pénzverés mindig is latin nyelvú volt. Így a keleti görög nyelvú lokális pénzverést nem azért szüntették be, mert görög nyelvú volt, hanem azért, mert pénzt most már csak az állam verhetett központilag. Itt csak tudatos pénzpolitikáról beszélhetünk, tudatos nyelvpolitikáról azonban semmi esetre sem.

A latin nyelv negyedik századi dominanciája a következő tényezőkkel magyarázandó. Először is, létezett egy mennyiségi faktor, amelyet egyben területi faktornak is tarthatunk. Közismert, hogy a tetrarchia bevezetése, a birodalom fölötti uralom lényegében négy részre osztása egyúttal területi megosztást is jelentett. A négy társcsászár négy uralmi övezeten osztozott, s mindegyik uralmi övezet császári székhelyet kapott. Mind a négy császári székhelyen kiépültek a központi adminisztráció szervei, az udvartartás stb. Az eddigi egy fővárossal és egy adminisztrációs központtal szemben négy foóváros és négy adminisztrációs központ ontotta a határozatokat, rendeleteket. S mivel a császár általában latin nyelvú volt, vagy legalábbis a császárhoz a kortársak véleménye szerint a latin nyelv illett, ${ }^{36}$ a császárt kiszolgáló udvari adminisztráció is latin nyelvú volt. Mindez a tetrarchiával megnégyszereződött. A területi megoszlásból következett, hogy a keleti rész két székhelyhez jutott: Diocletianus a Bosporus-parti Nikomédiában rendezte be udvarát, Galerius pedig, aki a keleti rész európai területeit kapta, Sirmiumban székelt. Noha a tetrarchia nemsokára megszúnt, a több központú közigazgatás megmaradt, s tovább élt a praefecturaszervezetben. ${ }^{37}$ Hogy a birodalom keleti részében állandó uralkodói és közigazgatási székhely jött létre, ezt a tényt nagyon fontosnak kell tartanunk a latin nyelv keleti használatának előtérbe kerülésében. Nikomédia, majd később még inkább a Byzantion helyén megalapított Constantinopolis, a második vagy új Róma, a római államot jelenítette meg a hellénizált kelet szivében.

${ }^{36}$ Ezt jól mutatja Zenobia esete, aki Palmyrát függetlenítette Rómától a 3. sz. 2. felében. Magát Augustanak nevezte, fiát, Vaballathust pedig Pius Felix Augustusnak. A Historia Augusta szerint (SHA Tyr.Trig. 30.20-21.) filios Latine loqui iusserat, ita ut Graece vel difficile vel raro loquerentur. ipsa Latini sermonis non usque quaque gnara, sed ut loqueretur pudore cohibita; loquebatur et Aegyptiace ad perfectum modum. A helyre már L. Hahn: i.m. 688. is hivatkozott.

${ }^{37}$ A praefecturák számát a kezdeti négyről Constantinus alatt háromra csökkentették, majd később visszaállították a négyes beosztást, még a negyedik században: pp Galliarum, pp Italiae et Africae, pp. Illyrici, pp. Orientis. A praefectus praetorio a maga területi illetékességén belül a császár teljhatalmú helyettese volt, ítéletével szemben nem volt fellebbezés, rendeleteket adhatott ki stb. 
Felvehetünk továbbá egy minőségi faktort is. Minőségi faktor alatt értem a latin nyelv megnövekedett presztízsét, amely a következó tényezókön alapult. A dominatus kialakulásával az állam életében a bürokrácia mindenhatóvá lett, a hivatalnokok száma ugrásszerúen felduzzadt. A bürokráciában végigjárható karrier vonzó életformává vált, biztos megélhetéssel kecsegtette a birodalom feltörekvő ifjúságát, mind Nyugaton mind Keleten. A negyedik század legnevezetesebb szofistája, az antiochiai Libanios (Kr. u. 314-393), Iulianus császár tanára, noha elismerte a római uralom pozitív vonásait, mégis féltette a görög kultúrát és ifjúságot a római életmódtól. Múveiben többször panaszkodik arról, hogy a görög ifjúság, pusztán a hivatali karriert és az ezzel járó hatalmat szem elôtt tartva, Rómába és Berytosba áramlik, hogy ott latin nyelvet és római jogot tanuljon, mivel csak ettól remélnek hasznot, és közben elhanyagolják a görög kultúrát, fơként a görög ékesszólást. ${ }^{38} \mathrm{~A}$ görög kultúráért rajongó, latinul nem tudó ${ }^{39}$ Libanios megjegyzéseiból tehát teljesen világosan kiderül, hogy a latin nyelv presztízse mennyire megnőtt a görögök szemében, de szerinte csak azért, mert a rómaiak nyelvének ismerete a hivatali karrier szempontjából elengedhetetlen volt.

De nemcsak a hivatali, hanem a hadseregben elérhetó karrier is növelhette a latin nyelv presztízsét, és tudjuk, hogy a hadsereg hivatalos nyelvhasználatában milyen domináns volt a latin. A hadsereg, mely a dominatus korában még inkább az állam támasza és létalapja volt, mint korábban, szintén biztos megélhetést és felemelkedési lehetőséget nyújtott az ifjúságnak, sốt - a bürokráciához hasonlóan, de annál valószínúleg jóval nagyobb mértékben - egyfajta menedéke is volt az állami terhek alól kibújni szándékozóknak, elsősorban a curialisoknak. ${ }^{40} \mathrm{Nem}$ véletlen,

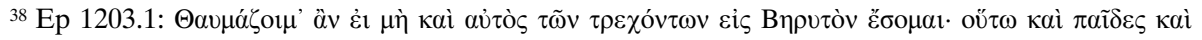

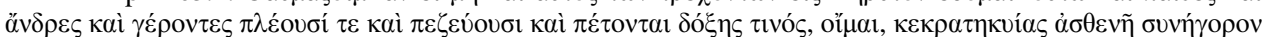

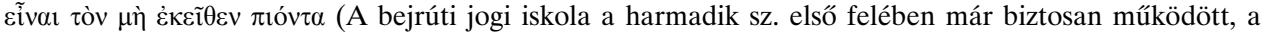
negyedik századra ugyanolyan híres elitképző lett, mint a római és a constantinopolisi jogi iskola); Or.

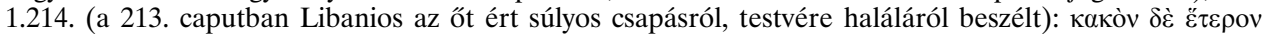

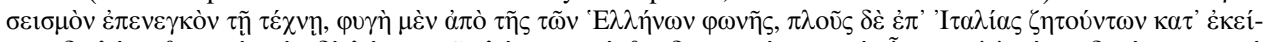

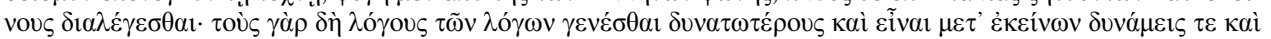

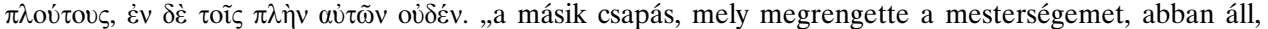
hogy menekülnek a görög nyelvtôl, és Itáliába utaznak azok, akik az ottaniak nyelvén akarnak beszélni: az ő beszédük ugyanis a mienknél erősebbé vált, és hatalom meg gazdagság jár vele, míg a mi beszédünk önmagán kívül más előnyt nem nyújt.” Hasonló gondolatokat találunk: Or. 2.44.3. skk., 48.22. skk., Epist. 951. és 1011. Joannes Chrysostomos is lefesti a latin nyelv és a római jog ismeretéból fakadó előnyöket, ugyanolyan negatív hozzáállással, mint Libanios, vö. Adversus oppugnatores vitae monasticae 3.5, PG 47, 357. o. Hozzáállása talán nem véletlen, hiszen a constantinopolisi patriarcha egykor Libanios tanítványa volt.

39 Több leveléból is kiderül, hogy nem tanult meg latinul: Epist. 434,2. 1004,4. 1036,2.

${ }^{40}$ A dominatus korában az állam egyre nagyobb mértékben sújtotta különféle munusokkal a curialis réteget. A curialisok szökése a városokból a késő́római jogalkotás ismétlődő tárgya volt, és az egyik kedvelt menedékhelyük a hadsereg volt, ahol a curiába való visszatérést előíró rendelkezés (CTh 12,1,22) ellenére még mindig a leginkább el tudtak vegyülni, vö. Alföldy G.: i.m. 123. Libanios is megjegyzi egyik beszédében (Or. 48.22.), hogy a latin nyelv, illetve a római jog tanulásától a curalisok közé tartozó görög ifjak azt is remélték — és nem alaptalanul —, hogy az ily módon megszerzett tudásuk révén kibújhatnak tanácsnoki munusaik alól. 
hogy e két terület ilyen presztízzsel rendelkezett, hiszen a dominatusnak köszönhetó „nyugalmi helyzet” haszonélvezője Hahn István szavai szerint, a senatori rend szúk körú arisztokráciáját leszámítva hovatovább már csak a császári bürokrácia és a hadsereg volt. ${ }^{41} \mathrm{~A}$ bürokráciában elsôsorban a római jog kötelezô ismerete révén, a hadseregben pedig különösen az egységes vezényleti nyelv miatt a latin nyelv ismerete elengedhetetlen volt, s ez a helyzet rendkívüli módon megnövelte presztízsét a görög anyanyelvú polgárok körében.

A latin nyelv presztízsének növekedéséhez keleten a negyedik században egy további, korábban szerepet nem játszó tényező is hozzájárult: a kereszténység, illetve az egyház. A keresztény egyház „hivatalos” nyelve kezdetben természetesen Nyugaton is a görög volt, de a latin nyelv már a második században kezdte kiszorítani a görögöt, és a negyedik századra teljesen a helyébe lépett. ${ }^{42} \mathrm{~A}$ második század végére létrejött a keresztény latin irodalmi nyelv, elsősorban Tertullianusnak köszönhetően, akinek múvei annyira népszerúek voltak, hogy némelyiket még görögre is lefordították. ${ }^{43}$ Tertullianus, Minucius Felix, Cyprianus, Arnobius, majd a negyedik században Lactantius, Hieronymus olyan múveket alkottak, melyek a keleti egyházak számára is tekintéllyel bírtak, olvasták és többnyire görögre is lefordították óket. Ennél is fontosabb azonban, hogy Constantinus és utódai pártfogásának köszönhetôen a keresztény egyház fokozatosan az állam részévé vált. Constantinus, aki mint fentebb láthattuk, a niceai zsinaton összegyúlt, többnyire görög anyanyelvú püspökökhöz hivatalos minőségében mindig latinul szólt, nyelvi magatartásával nagymértékben hozzájárulhatott ahhoz, hogy a görög egyházatyák a latint második vagy másik „hivatalos” egyházi nyelvnek tekintsék. Ehhez járult továbbá, hogy Róma püspöke a negyedik századra a latin nyelvú nyugati egyházak vezetójévé vált, és keleten is megpróbálta elfogadtatni vezető szerepét. A latin nyelv presztízsét jól mutatja az az új jelenség, hogy egy görög egyházatya (Athanasios) egy másik görög, igaz, eretneknek nyilvánított, arianus püspök (Auxentios) búnei között említi, hogy az illetô még latinul sem tud. ${ }^{44}$ $1992,398$.

${ }^{41}$ Vö. Ferenczy E.-Maróti E.—Hahn I.: Az ókori Róma története. (szerk. Harmatta J.) Budapest

42 A 2. századtól kezdve Rómában, Észak-Afrikában majd Galliában a keresztény közösségek már latinul érintkeznek egymással, vö. Christine Mohrmann: Die Rolle des Lateins in der Kirche des Westens. Theologische Revue 52 (1956) 1—18; 1. sk. A római egyház latinizálódását jól szemlélteti, hogy a 3. század közepétól a pápai sírfeliratok latin nyelvúek lettek, míg korábban a görög dominált, vö. Theodor Klauser: Der Übergang der römischen Kirche von der griechischen zur lateinischen Liturgiesprache. Th. Klauser: Gesammelte Arbeiten zur Liturgiegeschichte, Kirchengeschichte und christliche Archäologie. ed. E. Dassmann. Münster 1974, 184-194; 185., 9. jz. és 186. A nyugati keresztény közösségek fokozatos latinizálódása eredményeképpen először az egyházi adminisztrációból, majd a negyedik század második felében a liturgia nyelvhasználatából is kiszorul a görög nyelv: Th. Klauser: i.m. 188. és 193. szerint a váltás a liturgiában Damasus pápához és Ambrosius milánói püspökhöz köthető.

${ }^{43}$ Vö. Eusebios, Eccl Hist 2.2.4-5.

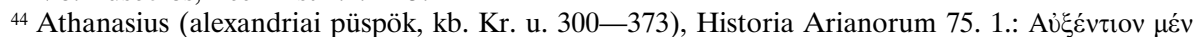

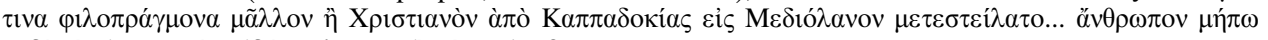

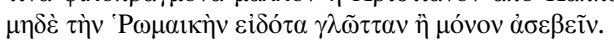


A latin nyelv tehát az itt felvázolt tényezóknek köszönhetóen a dominatus korában olyan presztízsre tett szert a görögök között, amirôl Cato és Cicero még csak nem is álmodhatott! Mi sem bizonyítja jobban ezt, mint az a teljesen újszerú jelenség, hogy eredetileg görög anyanyelvú alkotók, büszkén hangoztatva görög mivoltukat mégis inkább a latin nyelvet választották mondanivalójuk közlésére, és Rómát vagy Milánót tevékenységük színhelyéül. Az antiochiai születésú Ammianus Marcellinusban (kb. 330 - kb. 400) szokták látni az utolsó nagy római történetírót, míg az Alexandriában született Claudius Claudianusban (kb. 370—kb. 405) Róma utolsó nagy költőjét.

Úgy véljük, hogy a fentiekben már bebizonyítottuk, hogy a latin nyelv negyedik századi dominanciája keleten lényegében spontán folyamat eredményeképpen jött létre. ${ }^{45}$ Nézzünk meg itt utoljára egy sokszor idézett Libanios-helyet, melyet szocio-

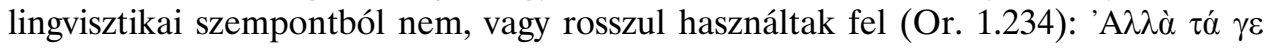

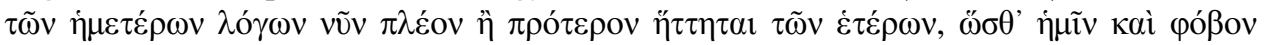

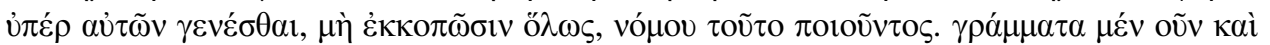

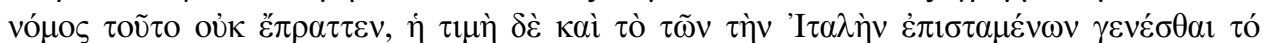

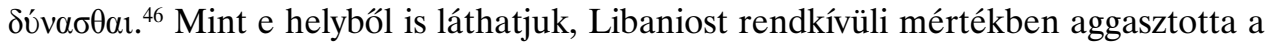
görög ékesszólás hanyatlása és a latin beszéd népszerúsége, és ezért egyértelmúen a római jogot, ill. annak nyelvét, a latint hibáztatta, mivel ezek révén lehetett felemelkedni korának társadalmi ranglétráján. E helyen nyomatékosan kijelenti, hogy a görög ékesszólás hanyatlását nem valamiféle törvényi eloórás okozta, hanem a latin nyelvtudással együtt járó $\tau \imath \eta \eta$, azaz presztízs és a hatalom. E helyből véleményünk szerint nem nagy merészség azt is kiolvasni, hogy nem létezett olyan rendelkezés, mely háttérbe szorítani kívánta volna a görög nyelvet a latin javára. ${ }^{47}$ Nagyon való-

${ }^{45}$ Ezen állítás igazságtartalmát nem csökkenti az a tény sem, hogy Constantinus és dinasztiájának utódai esetében személyes törekvést figyelhetünk meg, hogy a hivatalos megnyilatkozásaiknál a latin nyelvet használják, keleten nyilván görög tolmácsolással. Már Kaimio kimutatta, hogy a principatus-kori császárok személyes nyelvi attitúdje csak kis mértékben tudta a birodalom hivatalos nyelvhasználatának dichotomiáját befolyásolni. Mi a finn kutató megállapításának érvényét a dominatus korára is kiterjesztjük.

46 „Hanem a görög beszédmúvészetet - mostanában sokkal inkább, mint korábban — oly mértékben háttérbe szorítja a latin, hogy elfogott bennünket a félelem: teljesen kiszorítja a mienket, minthogy a törvény [tkp. a jogtudomány] ezt eredményezi. Rendelet vagy törvény azonban ezt nem okozta, hanem a latintudással együtt járó tekintély és a hatalom.”

${ }^{47}$ Annál inkább meglep minket, hogy Henri Irénée Marrou: Histoire de l'éducation dans l'antiquité. Paris 19767 , 378. oldalon ezt a Libanios-helyet a következő összefüggésben említi: „il semble bien (Lib. Or. 1,234) qu'il y ait eu chez Dioclétien et ses successeurs une politique consciente, visant à développer en Orient la connaissance de la «langue nationale», envisagée comme un facteur d'unité pouvant renforcer la cohésion de l'empire." Itt jegyezzük meg: Kendeffy Gábor felhívta a figyelmünket arra, hogy az Or. 1.234. idézett mondata azt az értelmezést is megengedné, hogy esetleg létezett olyan rendelkezés, amely mondjuk, elő́rta volna a latin szónoklást, de ez nem okozta a görög hanyatlását, hanem az ismert okok. $\mathrm{Ez}$ az értelmezési lehetőség azonban csak elméletileg lehetséges, ugyanis tényleg nem tudunk olyan rendelkezésrôl, amely a latin nyelvú szónoklást írta volna elő a görög helyett. 
színúnek túnik, hogy Libanios még csak el sem tudta képzelni, hogy egy ilyesfajta „nyelvtörvény” egyáltalán létezhet. ${ }^{48}$

A 3-4. században tehát módosult a birodalom hivatalos nyelvhasználati tradíciója, de ez nem felülról irányított nyelvpolitika, hanem spontán folyamat eredménye volt. E tradíció módosulását pedig elsôsorban a császári székhely keletre helyezése és a latin nyelv megnövekedett presztízse váltotta ki. Ha lett volna tudatos nyelvi szabályozás, akkor azt Libanios, a görög kultúra és nyelv harcos védelmezóje nyilván említette és a megfelelő bírálatban részesítette volna. Megállapíthatjuk tehát, hogy a kortárs Libanios sokkal jobb választ adott a latin nyelv dominanciájának kérdésére, mint a huszadik századi kutatók többsége, akiket a modern kor nyelvhasználatot törvényileg szigorúan szabályozni igyekvő törekvései, melyek a tizenkilencedik században a nemzetállamok kialakulásával jelentek meg, teljesen félrevezettek.

${ }^{48}$ Ez a megállapításunk összhangban van Kaimio véleményével, miszerint az antikvitásban a hivatalos nyelvhasználat kérdése egyáltalán nem, vagy csak kevéssé volt fontos, illetve, hogy a nyelvhasználatot nem annyira valamiféle szabályozás mint inkább a tradíció irányította. 